\title{
What Increases Breast Cancer Risk? Is there a way to Reduce Breast Cancer Risk?
}

\author{
*Saeed Nasouhipur \\ Department of Hematology, Faculty of pirapezeshki, Tabriz University of medical sciences, Iran
}

Submission: August 08, 2017; Published: August 09, 2017

${ }^{*}$ Correspondence Address: Saeed Nasouhipur, Department of Hematology, Faculty of pirapezeshki, Tabriz University of medical sciences, Iran, Email: snasouhipur1331@gmail.com

Abstract

In 1940 the lifetime risk of a woman developing breast cancer was $5 \%$ or one in 20. The American Cancer Society estimates that risk being $13 \%$ in 2012 or more than one in 8 . This year an estimated more than 240000 women in the USA will be diagnosed with breast cancer. Why and what has changed over the years that this disease has developed?

\section{Introduction}

Cancer is one of the scariest words in our language, and possibly the worst news we can get from doctors, and no one can prepare for hearing the words" you have breast cancer". There are myths about cancer that the most common myths about cancer include: cancer is genetic so nothing can prevent whether or not you are diagnosed. This is one of the biggest myths because experts estimate that more than half of cancer diagnoses can be prevented. A vast majority of cancers are caused by environment toxicity.

The other myth is, Alcohol is good for my health. While a glass of red wine has proven beneficial to heart health, alcohol causes inflammation. A state of chronic inflammation has been linked to cancer, heart disease, diabetes, and many other diseases. Breast cancer is the most common cancer in women. The breast cancer genes only 5 to $10 \%$ of breast cancer cases today and those are ancient, stable abnormalities. They have not changed. But what has changed over the years, are changes in our outside environment and our body's inside environment. So in terms of the inside environment, with obesity making, extra inside hormones that can influence breast cell growth, it also triggers more insulin growth factor. Research done at Harvard Medical School's cancer center foundation $80 \%$ of all cancers will mutate and mimic the effect of insulin.

In fact, their current research is focused on finding an "insulin inhibitor" for use in cancer treatment. There are three primary categories that lend to endocrine disruption which women need to be aware: diet, lifestyle, and environment.
What a woman eats directly affects how her body produces and expresses hormones, as does the way she lives her daily life. The environment in which a women lives - and especially the types of toxins she's exposed to on a daily basis - are another major contributing factor to endocrine disruption. We live in a toxic world, whether it's pesticides on our food, and heavy metals in our water, orbisphenol-s in baby bottles. While In the beginning, the earth was perfect and free of chemical toxins that interfere with human biology. But today, humanity faces a barrage of endocrine-disrupting chemicals (EDCs) that target virtually every glandular system responsible for producing hormones [1].

On the other hand we don't have a healthy diet and we lead very stressful lives. Even the world Health organization that monotors global health risks say, stress is literally becoming an epidemic. Stress is one of the most damaging factors that contribute to endocrine dysfunction, and it can arise from many different things. More women are drinking alcohol. Use of alcohol is linked to increases risk of developing breast cancer [2]. Compared with nondrinkers, women who consoume one alcoholic drink a day have a very small increase in risk, and those who have 2 to 5 drinks daily have about 1.5 times the risk of women who do not drink. More women have not stopped smoking. More women have not adequate sleep; this is a problem because less sleep means stress. And more stress means more disease. They run themselves ragged. In many cases it's not known why a woman gets breast cancer. In fact, $75 \%$ of all women with breast cancer have no known risk factors [3]. 


\section{Cancer Therapy \& Oncology International Journal}

\section{Conclusion}

Only $5-10 \%$ of breast cancer cases are due to an inherited genetic mutation [8]. The other $90 \%$ mostly are due to lifestyle, reproductive, and environmental factors. Research has proven that there are clear, actionable everyday steps every woman and girl can take to lower her risk of breast cancer. So, the first line of defense against breast cancer is to choose a healthy lifestyle [6]. And for having a better life, it is necessary that: Reduce the tensions of life, don't smoke, Eat a diet in fruits, vegetables, and low in saturated fat, Exercise regularly, Maintain a healthy weight, control blood pressure, Don't drink alcohol, because use of alcohol is linked to increase in risk of developing breast cancer, Get adequate sleep, [6] use adequate from sunlight and vitamin D. Learn ways to keep stress down and Don't let stress control you. Avoid or limit hormone replacement therapy.

But about Density matters: Research has shown that dense breasts can be six times most likely to develop cancer. So, if you have dense breasts, you have a higher than average risk of breast cancer. so you need to develop a screening plan.

General recommended screening for dense breasts guidelines include:
- A monthly breast self exam.

- A yearly breast exam by your doctor.

- A digital mammogram every year starting at age 40.

Your personal screening plan also may include the following tests to detect any cancer as early as possible: MRI and ultrasound of the breasts.

\section{References}

1. On the breast cancer gene, Interviews of Dr. Marisa Weiss, founder of Breast cancer org (2012) oncologist, Breast cancer specialist, USA.

2. Taking new aim at cancer (2016) Harvard Health Publications, Harvard Medical School, USA.

3. Ty Bollinger (2015) Myths about cancer. The truth about cancer, USA.

4. Endocrine Disruptores what women need to avoid to protect their hormones (2017) Organixx.

5. Risk Factors for Breast cancer (2014) Breast cancer Health center, UK.

6. Whole Detox- Dr Deanna Minich (2016).

7. How to boost your immune system-Harvard (2016) Health publications, Harvard Medical School.

8. New class of Breast cancer Drug Deemed well- Tolerated (2017) Lab Roots cancer newsletter.

Your next submission with Juniper Publishers will reach you the below assets

- Quality Editorial service

- Swift Peer Review

- Reprints availability

- E-prints Service

- Manuscript Podcast for convenient understanding

- Global attainment for your research

- Manuscript accessibility in different formats

( Pdf, E-pub, Full Text, Audio)

- Unceasing customer service

Track the below URL for one-step submission https://juniperpublishers.com/online-submission.php 